\title{
PENGARUH KECERDASAN EMOSIONAL DAN SPIRITUAL TERHADAP AKHLAK SISWA DI SEKOLAH MENENGAH PERTAMA SE-KECAMATAN BANGKINANG KOTA
}

\author{
Nurhadi $^{1} \&$ Fitria $^{2}$ \\ STAI Al-Azhar Pekanbaru; UIN Suska Riau \\ alhadijurnal@gmail.com ; fitria14567@gmail.com
}

\begin{abstract}
This study aims to find the effect of emotional and spiritual intelligence on the morals of students in junior high schools in Bangkinang City District. The purpose of this study are three, namely: 1. To determine the effect of emotional intelligence on the morals of students in the First Middle School in Bangkinang District. To find out the effect of spiritual intelligence on students' behavior in the First Middle School in Bangkinang City District. 3. To find out the significant influence between emotional and spiritual intelligence on the morals of students at the First Middle School in Bangkinang Kota sub-district. This research is a correlational research with a quantitative approach. The population of this study was 2205 students. Research samples were 399 students. Sampling using Slovin formula with an error rate of 5\%, sampling technique using Stratified Random Sampling. Data collection techniques in this study using a questionnaire and data analysis techniques using multiple regression. From the results of the study obtained that there is an influence between emotional intelligence on student morals with a Significant value of $0,000<0.05$. There is an influence between spiritual intelligence on student morals with a Significant value of $0,000<0.05$. Then there is a significant influence of Emotional and Spiritual Intelligence on the Morals of Students in Junior High Schools in Bangkinang City District with a Significant value of 0,000 <0.05.
\end{abstract}

Keywords: Emotional Intelligence, Spiritual Intelligence, Student Morals.

\begin{abstract}
Abstrak: Penelitian ini bertujuan untuk menemukan pengaruh kecerdasan emosional dan spiritual terhadap Akhlak Siswa di Sekolah Menengah Pertama Se-Kecamatan Bangkinang Kota. Tujuan dari penelitian ini ada tiga yaitu : 1. Untuk mengetahui pengaruhkecerdasan emosional terhadap akhlak siswa di Sekolah Menegah Pertama Se-kecamatan Bangkinang Kota.2. Untuk mengetahui pengaruhkecerdasan spiritual terhadapakhlak siswadi Sekolah Menegah Pertama Se-kecamatan Bangkinang Kota. 3. Untuk mengetahui pengaruh yang signifikan antara kecerdasan emosional dan spiritual terhadap akhlak siswa di Sekolah Menegah Pertama Se-kecamatan Bangkinang Kota. Penelitian ini merupakan penelitian korelasional dengan pendekatan kuantitatif. Populasi penelitian ini berjumlah 2205 siswa. Sampel penelitian sebanyak 399 siswa. Pengambilan sampel menggunakan rumus Slovin dengan tingkat error 5\%, Teknik pengambilan sampel menggunakan Stratified Random Sampling. Teknik pengumpulan data pada penelitian ini menggunakan angket dan teknik analisis data menggunakan regresi berganda.Dari hasil penelitian diperolehbahwa ada pengaruh antara kecerdasan emosional terhadap akhlak siswa dengan nilai Signifikan $0.000<$ 0.05. Ada pengaruh antara kecerdasan spiritual terhadap akhlak siswa dengan nilai Signifikan $0.000<0.05$. Kemudian terdapat pengaruh yang signifikan dari Kecerdasan Emosional dan
\end{abstract}


Spiritual terhadap Akhlak Siswa di Sekolah Menengah Pertama Se-Kecamatan Bangkinang Kota dengan nilai Signifikan $0.000<0.05$.

Kata Kunci: Kecerdasan Emosional, Kecerdasan Spiritual, Akhlak Siswa

\section{PENDAHULUAN}

Dunia pendidikan sangat besar pengaruhnya dalam perubahan akhlak seseorang. Karena salah satu tujuan pendidikan nasional yaitu membentuk akhlak mulia. Berbagai ilmu diperkenalkan agar siswa dapat memahami dan melakukan suatu perubahan pada dirinya. Pembinaan akhlak dalam ajaran agama Islam merupakan bagian integral dari keseluruhan ajaran agama Islam yang harus dibuktikan dengan perbuatan. Sebagai seorang manusia yang beragama, sudah tentu akhlakul karimah diperlukan agar bergaul dengan baik. Baik itu dalam kehidupan keluarga, sekolah maupun ditengah-tengah masyarakat, dengan begitu akhlak tersebut harus dibina dan dipelihara supaya tidak hilang dari diri manusia tersebut. Sekolah merupakan tempat anak berinteraksi, sekolah harus membangun aspek moral, cinta kasih, demokrasi, toleransi, menghargai perbedaan, berlapang dada menerima kenyataan dan menjauhkan diri dari nilai-nilai kekerasan. Sekolah harus meningkatkan kecerdasan emosional siswa, karna setiap pengalaman yang melibatkan emosi ekstrem akan memberikan efek langsung yang lebih nyata pada prilaku anak sekaligus efek jangka panjang pada perkembangan kepribadian mereka. ${ }^{1}$ Manusia merupakan makhluk yang paling sempurna dan mulia di muka bumi ini,karena kesempurnaan itulah manusia dikaruniai berbagai potensi yang luar biasa diantaranya adalah kecerdasan Intelektual, IQ merupakan potensi dasar manusia dan merupakan faktor genetik. Para ahli berkeyakinan,semakin tinggi IQ seseorang semakin tinggi pula orang itu menunjukkan kemampuannya.Pola pendidikan di Indonesia selama ini terlalu mengedepankan Kecerdasan Intelektual (IQ) dan materialisme, tetapi mengabaikan Kecerdasan Emosional dan juga Spiritual. Pada umumnya masyarakat memandang bahwa IQ adalah hal utama yang harus diperhatikan, dengan mengesampingkan EQ dan SQ, sehingga anak pintar itu merupakan sebuah kebanggan, tanpa mereka sadari

${ }^{1}$ Djazimi, "Pengarub Kecerdasan Emosional Terhadap Akblak. Siswa Madrasah Aliyah AlKhairiyah Provinsi Banten”, Studia Didkatika Jurnal Ilmiah Pendidikan, Vol.10, No.2, 2016, h. 49 
bahwa banyak anak pintar dan berprestasi akan tetapi tidak pandai bergaul, terjebak pergaulan bebas, narkoba, tawuran dan lain sebagainya. Maka dari itu IQ tanpa adanya EQ dan SQ akan sia-sia.

Dalam kehidupan modern dan kondisi masyarakat yang semakin tertata ini hendaknya antara kebutuhan duniawi dan ukhrowi bisa sejalan. Dengan adanya konsep ESQ (Emotional-Spiritual Quotient) atau kecerdasan emosi dan kecerdasan spiritual, diharapkan antara kebutuhan duniawi dan ukhrowi tidaklah bertentangan akan tetapi mampu untuk berjalan bersama-sama dalam menghantarkan tujuan dan hakikat manusia yang sesunggguhnya. ${ }^{2}$ Goleman mengatakan para ahli psikologi sepakat bahwa IQ hanya mendukung 20\% faktor yang menentukan keberhasilan, sedangkan $80 \%$ sisanya berasal dari faktor lain dan salah satunya adalah kecerdasan Emosional. ${ }^{3}$ Ary Ginanjar didalam bukunya mengemukakan pendapat dari Danah Zohar dan Ian Marshall mereka mendefenisikan kecerdasan spiritual adalah kecerdasan untuk mengahadapi persoalan makna dan velue, yaitu kecerdasan untuk menempatkan prilaku dan hidup kita dalam konteks makna yang lebih luas dan kaya, kecerdasan untuk menilai bahwa tindakan atau jalan hidup seseorang lebih bermakna dibandingkan dengan yang lain. ${ }^{4}$ Dari pengertian diatas jelas bahwa kecerdasan spiritual diperlukan untuk memfungsikan Kecerdasan Emosional dan Kecerdasan Intelektual. Namun pada kenyataannya masih banyak masyarakat kita yang menjadikan Spiritual menjadi hal yang tidak penting dalam pendidikan. Tanpa mereka sadari berapa banyak anak yang pada akhirnya lari kepada zat adiktif karna merasa tertekan, menjadi garang dan bahkan melakukan tindak kekerasan ketika marah, jatuh kejurang seks bebas, tawuran antar pelajar. Ini semua terjadi tidak lain karena kurangnya pendidikan Spiritual, karena seyogyanya Kecerdasan Spiritual adalah kemampuan untuk memberikan makna spiritual terhadap pemikiran, perilaku dan kegiatan, serta mampu menyinergikan IQ, EQ dan SQ secara komprehensif. ${ }^{5}$ 2012), h. 70

${ }^{2}$ Hamzah B. Uno, Orientasi Barudalam Psikologi Pembelajaran, ( Jakarta : PT. Bumi Aksara,

${ }^{3}$ Ni Luh Putu Ani Cahyani, Pengarub Kecerdasan Emosonal, Motivasi, dan Pelatihan terhadap Kinerja Aparatur Sipil Negaradi BiroUmum Sekretariat Daerah Provinsi Sulawesi Utara.

${ }^{4}$ Ary Ginanjar, Rahasia Sukses Membangun Kecerdasan Emosi dan Spiritual ESQ Emotional Spiritual Quotion The ESQ Way 1651 Ihsan 6 Rukun Iman dan 5 Rukun Islam, (Jakarta: Penerbit Agra, 2007), h. 13

$$
{ }^{5} \text { Ibid., }
$$


Salah satu masalah yang terjadi pada zaman sekarang adalah cara menempatkan nilai dan orientasi keagamaan di tengah-tengah perubahan yang terus berkembang cepat dalam kehidupan sosial. Dalam transisi seperti ini sering bahkan banyak diantara anak yang ingin meninggalkan sistem lama yang menurut mereka menjadi penghambat dalam proses modernisasi, namun di sisi lain kita belum menemukan sistem baru yang sesuai, yang dapat dijadikan sebagai pedoman dalam menentukan sikap di kehidupan sosial. Oleh karena itu penting untuk mengupayakan nilai-nilai keagamaan Islam dan juga kecakapan emosiserta spiritual dalam proses modernisasi dan perubahan sosial dengan pendekatan yang lebih terbuka, dialogis dan kontekstual.Berdasarkan studi pendahuluan melalui observasi pada bulan April 2019 lalu, ditemukan beberapa kecerdasan emosional yang sudah baik di SMP SeKecamatan Bangkinang Kota dengan gejala-gejala :

a. Siswa memahami emosi temannya

b. Siswa menolong guru ketika memerlukan bantuan

c. Siswa mau membantu teman yang membutuhkan bantuan

Dengan kecerdasan emosional anak memiliki kemampuan untuk mengenali emosi diri dan temannya, meraih dan membangkitkan perasaann untuk membantu pikiran, dan memahami perasaan dan maknanya, dan mengendalikan perasaan secara mendalam sehingga membantu perkembangan emosi dan intelektual. ${ }^{6}$ Seorang anak yang memiliki kecerdasan emosional yang baik ia akan mampu mengenali dan mengelola emosi diri, ia mampu untuk memotivasi dirinya sendiri dan juga oranglain, bisa mengenali perasaan oranglain serta memiliki hubungan yang baik dengan orang lain. kemudian dengan observasi awal yang sudah dilakukan ditemukan kecerdasan spiritual yang sudah baik dengan gejala-gejala :

a. Siswa mau menyisihkan sedikit uang jajannya untuk infak sekolah

b. Siswa mau meminjamkan alat belajar kepada teman yang tidak memiliki alat belajar

c. siswa menyalami guru ketika bertemu.

Anak-anak yang memiliki kecerdasan spiritual yang baik dapat membangun relasi dengan apa yang ada diluar dirinya, tidak hanya sekedar relasi yanga da diliarnya,

${ }^{6}$ Hamzah B.uno 
ia juga mampu untuk menjaga relasi diri dengan Tuhannya, relasi sudut oandang sosial keagamaanya, dan juga relasi sudut pandang etika keagamaannya. ${ }^{7}$

Berdasarkan observasi pada bulan April 2019 yang dilakukan peneliti di Sekolah Menengah Pertama Se-Kecamatan Bangkinang Kota bahwa guru telah memberikan bekal dan pembelajaran yang mendukung kecerdasan emosional dan spiritualnya, dengan mengajarkan materi-meteri ajar yang dapat meningkatkan kecerdasan emosional dan spiritual anak dengan baik, akan tetapi masih banyak siswa melakukan hal yang terlihat menyimpang dari akhlakul karimah seperti memilih-milih teman dalam bergaul, mengejek teman dengan kata-kata yang tidak pantas, memalak temannya, berkata kasar terhadap temannya, tidak sopan kepada gurunya, bahkan salah satu gurunya mengatakan bahwa anak-anak di sekolah tersebut masih sulit untuk diajak sholat berjamaah yang diterapkan disekolah. Adapun gejala-gejala awal yang peneliti temukan adalah :

1) Masih ada siswa yang kurang peduli terhadap kesulitan orang lain

2) Masih ada siswa yang tidak sopan kepada gurunya

3) Masih ada siswa yang mengejek-ejek teman

4) Masih ada siswa yang berkata kasar dan tidak pantas

5) Masih ada siswa yang tidak melaksanakan sholat berjamaah

6) Masih ada siswa yang berlarian anata laki-laki dan perempuan

\section{PEMBAHASAN}

\section{Kecerdasan Emosional}

Teori yang dikutip oleh Steven J Stein dan Howard E.Book yang dikemukakan oleh Reuven Bar-On didalam buku Hamzah B.Uno mengatakan bahwa kecerdasan emosional adalah serangkaian kemampuan, kompetensi, dan kecakapan non kognitif yang memengaruhi kemampuan seseorang untuk berhasil mengatasi tuntunan dan tekanan lingkungan. Kemudian Steven J Stein dan Howard E.Book menjelaskan pendapat Peter Salovey dan John Mayer sebagai pecipta Istilah kecerdasan emosional, bahwa kecerdasan emosional adalah sebuah kemampuan

${ }^{7}$ Sukidi, Rahasia Sukses Hidup Bahagia Kecerdasan Spiritual Mengapa SQ Lebih Penting daripada IQ dan EQ, (Jakarta: Gramedia, 2002), h. 80-85 
untuk mengenali perasaan, meraih dan membangkitkan perasaan untuk membantu pikiran, memahami perasaan dan maknanya, dan mengendalikan perasaan secara mendalam sehingga membantu perkembangan emosi dan intelektual. ${ }^{8}$ Dengan kata lain menurut Stein dan Book, EQ adalah suatu kecakapan yang memungkinkan kita melapangkan jalan di dunia yang rumit, mencakup aspek pribadi, sosial dan pertahanan dari seluruh kecerdasan, akal sehat yang penuh misteri, dan kepekaan yang penting untuk berfungsi secara efektif setiap hari. Dalam bahasa sehari-harinya kecerdasan emosional biasa disebut dengan "street smarts (pintar) atau kemampuan khusus yang kita sebut dengan "akal sehat". Kecerdasan emosi merupakan kondisi mental yang dimiliki seseorang yang bersifat gradasi dalam arti setiap orang mempunyai tingkat yang berbeda-beda. Hal ini sejalan dengan pendapat Agustian yang mengatakan bahwa kecerdasan emosi adalah kemampuan untuk merasa yang terletak pada kejujuran terhadap suara hati. William James menyatakan bahwa emosi sebagai keadaan budi rohani yang berhubungan dengan kondisi dirinya. Hal ini sesuai dengan pendapat Goleman menyatakan bahwa koordinasi suasana hati merupakan inti dari hubungan sosial yang baik. Bila seseorang pandai menyesuaikan diri dengan suasana hati individu yang lain, orang tersebut memiliki tingkat emosionalitas yang baik dan akan lebih mudah menyesuaikan diri dalam pergaulan sosial dan lingkungan sekolahnya. ${ }^{9} J a d i$, kecerdasan emosional adalah sesuatu yang ada didalam diri seseorang berupa kemampuan, kompetensi, kecakapan non-kognitif dalam artian bukan kecakapan berfikir melainkan sebuah kecakapan untuk bisa memahami perasaan, mengendalikan perasaan sehingga membantu perkembangan emosi dan intelektual.

\section{Unsur-Unsur Kecerdasan Emosional}

Kecerdasan emosional sebuah kekuatan yang tersembunyi dalam diri seseorang untuk menjalani kehidupannya. Adapun unsur-unsur dari kecerdasan emosional ini adalah:

\footnotetext{
${ }^{8}$ Hamzah B. Uno, Loc.cit.,

${ }^{9}$ A.A.Anwar Prabu Mangkunegara dan Mela Puspitasari, kecerdasan Emosi, Stres Kerja dan Kinerja Guru, Jurnal Pendidikan,Vol. 45, Nomor 2, November 2015, h. 142-255
} 
a. Kemampuan mengenali emosi $\operatorname{diri}^{10}$. Mengenali emosi diri merupakan inti dari kecerdasan emosional, yaitu kesadaran atas perasaan diri sendiri ketika perasaan itu timbul. Ada tiga kemampuan yang merupakan ciri-ciri mengenali emosi diri sendiri (kesadaran diri), yaitu: a). Kesadaran emosi.b). Penilaian diri secara teliti. c). Percaya diri.

b. Kemampuan mengelola emosi diri. Berikut karakteristik dari perilaku yang menggambarkan seseorang mempunyai kemampuan mengelola emosi diri, antara lain:a. Mampu mengelola amarahnya dengan baik dan bersikap toleran terhadap frustasi. b. Mampu mengungkapkan amarah dengan tepat. c. mampu mengendalika prilaku agresif yang dapat merusak diri sendiri dan orang lain. d. Memiliki kemampuan untuk mengatasi tekanan ( stress). e. Dapat mengurangi rasa kesepian dan mudah bergaul.

c. Kemampuan memotivasi diri dan orang lain. Ada empat kecakapan utama dalam kemampuan memotivasi diri sendiri dan orang lain, yaitu: a. Dorongan untuk berprestasi. b. Komitmen. c. Inisiatif. d. Optimis

d. Kemampuan mengenali emosi orang lain. Atau yang disebut juga dengan istilah empati, Empati di dalam kamus psikologi berarti sebuahpemahaman dan kesadaran kognitif terhadap emosi danperasaan orang lain.Empati adalah suatu suasanasikap psikologispribadi yang berusaha untuk menempatkandiri pada suasana psikologis orang lain. Empatimencerminkankesediaan untuk menempatkan diri dalamposisi orang lain.Denganberempati seseorang akan bisa memahami perasaan oranglain meskipun tidak berarti menyetujui. ${ }^{11}$

e. Kemampuan membina hubungan dengan orang lain yang disebut juga dengan keterampilan sosial. Adapun karakteristik orang yang memiliki kemampuan membina hubungan dengan orang lain adalah : a. Memiliki pemahaman dan menganalisis hubungannya dengan orang lain. b. Memiliki sikap bersahabat ataupun mudah dan dapat hidup selaras dengan kelompok. c. Bersikap senang berbagi rasa dan bekerja sama.

${ }^{10}$ Daniel Goleman, Emotional Intelligece, (Jakarta : Gramedia Pustaka Utama,1996), h. 58

${ }^{11}$ Nurul Zuriyah, Pendidikan Moral dan Budi Pekerti dalamPerspektif Perubahan, Jakarta: Bumi Aksara, 2008), h. 37 


\section{Faktor-Faktor yang mempengaruhi Kecerdasan Emosional}

Ada beberapa faktor yang dapat mempengaruhi perkembangan kecerdasan emosional seseorang diantaranya: a. Faktor Internal meliputi : 1) Faktor Hereditas yaitu faktor bawaan atau bakat dan ia masuk dalam kategori faktor internal yang dapat mempengaruhi kecerdasan emosional seseorang. 2) Agama, Agama memberikan pondasi yang kuat pada diri seseorang agar jiwanya tangguh tak mudah tergoncang oleh apapun.a. Faktor eksternal. 1) Keluarga. Keluarga memiliki peran yang sangat pentingdalam upaya mengembangkan pribadi anak.Kasih sayang orang tua akan pendidikantentang nilai-nilai kehidupan, baik agama maupun sosialbudaya yang diberikannya merupakan faktor yangkondusif untuk mempersiapkan anak menjadi pribadi dananggota masyarakat yang sehat dan baik. 2) Lingkungan. John Locke berpendapat bahwa seorang anak yang baru lahir bagaikan selembar kertas putih yang belum ternoda oleh apapun. Kemudian orang tuanyalah (lingkungan) yang akan memberikan noda tinta kepada kertas putih itu. Teori itu kemudian disebut dengan teori Tabularasa. Jadi dapat dikatakan bahwa perkembangan kecerdasan seorang anak sangat dipengaruhi oleh orang tua, lingkungan dan pengalaman dari anak tersebut. Terutama masyarakat yang memiliki andil dalam faktor lingkungan ini. $^{12}$

\section{Kecerdasan Spiritual}

Danar Zohar dan Ian Marshall bahwa spiritual berasal dari bahasa latin yang artinya prinsip memfasilitasi suatu organisme, dan juga dari bahasa latin sapienta (sophia dalam bahsa yunani) yang artinya adalah kearifan dan kecerdasan kearifan. Spritual juga merupakan hal-hal yang menyangkut kemanusiaan yang bersifat non materi yang terdapat dan terselubung didalam jiwa dan juga hati manusia seperti : kebaikan, kebenaran, keindahan, kesucian. ${ }^{13}$ Kecerdasan spiritual ini juga mengenai hati nurani yang lebih hebat dari semua jenis kecerdasan, kecerdasan ini juga dipandang sebagai unsur pokok untuk mencapai kesuksesan sejati. Anak yang memiliki IQ tinggi belum tentu dapat mengatasi berbagai masalah dihidupnya, kecuali

${ }^{12}$ Nurul Zuriyah, Ibid., h. 37

${ }_{13}$ Baharuddin dan Rahmatia Zakaria, pengarub kecerdasan Spiritian Terhadap Peningkatan Kinerja Guru di SMA Negeri 3 Takalar Kabupaten Takalar, Jurnal Idaarah, Vol.2, No.1, Juni 2018, Malang: Fakultas Tarbiyah dan Keguruan UIN Alauddin Makasar. 
jika ia memiliki SQ yang tinggi. ${ }^{14}$ Ary Ginanjar mengatakan bahwa kecerdasan spiritual merupakan kemampuan untuk memberi makna ibadah terhadap setiap prilaku dan kegiatan, melalui langkah-langkah dan juga pemikiran bersifat fitrah, menuju manusia seutuhnya, dan memiliki pemikiran tauhid, serta berprinsip hanya karena Allah. Kecerdasan spiritual ini penting dimiliki oleh sang anak karena jika tanpa kecerdasan ini hati anak akan menjadi hampa, kekosongan hati tanpa kecerdasan ini akan membuatnya menjadi seseorang yang ganas, layaknya seorang monster. Dalam Islam, kecerdasan spiritual termasuk dalam kecerdasan qalbu, seperti yang dikatakan Abdul Mujib dan Jusuf Mudzakir bahwa kecerdasan spiritual adalah kecerdasan qalbu yang berhubungan dengan kualitas bathin seseorang. Kecerdasan ini mengarahkan seseorang untuk berbuat lebih manusiawi, sehingga dapat menjangkau nilai-nilai luhur yang mungkin belum tersentuh oleh pikiran manusia. ${ }^{15}$

\section{Karakteristik Kecerdasan Spiritual}

Marsha Sinentar menjelaskan ada beberapa ciri dari anak yang memiliki potensi kecerdasan spiritual yang tinggi. Karakteristik ini biasanya dapat dilihat ketika anak menuju remaja dan akan matang ketika ia dewasa. Akan tetapi tentu saja potensi ini berkembang tidak lepas dari pengaruh lingkungannya seperti keluarga dan masyarakat (teman sebaya). Berikut adalah karakteristiknya ${ }^{16}:$ a. Kesadaran diri yang mendalam, intuisi yang tajam, kekuatan keakuan(ego-strenght) dan memiliki otoritas bawaan. Ciri utama dari munculnya kesadaran diri yang kuat adalah memiliki kemampan memahami dirinya sendiri dan emosi yang muncul sehingga mampu berempati terhadap apa yang terjadi kepada orang lain. selain itu anak-anak yang memiliki kesadaran yang mendalam ini memiliki intuisi yang tajam, bisa melihat kejadiankejadian yang akan datang, sehingga ia bisa mengendalikan prilakunya, anak yang seperti inijuga memiliki kemampuan untuk mengendalikan alam bawah sadarnya, sehingga prilaku anak akan seperti sosok dewasa yang matang. b. Anak memiliki pandangan yang luas terhadap dunia dan alam. Ia sadar bahwa dirinya dan orang lain

${ }^{14}$ Jhon. P.Miller, Cerdas di Kelas Sekolah Kepribadian, Terjm. Abdul Munir Mulkhan, ( Yogyakarta : Kreasi Wacana, 2002), h.3

${ }^{15}$ Abdul Mujib \& Jusuf Mudzakir, Nuansa-NuansaPsikologi Islam, (Jakarta: Rajawali Press, 2001), h. 329-330

16 Triantoro Safaria, Spiritual Intellegence Metode Pengembangan Kecerdasan Spiritual Anak, (Yogyakarta : Graha Ilmu,2007), h. 26 
saling berkaitan, sehingga anak sadar bahwa alam dan manusia itu bersahabat, yang pada akhirnya sang anak memiliki perhatian yang mendalam terhadap alam sekitarnya dan mampu melihat bahwa alam raya ini diciptakan oleh zat yang maha tinggi yaitu Allah SWT. c. Moral tinggi, pendapat yang kokoh, kecenderungan untuk merasa gembira, mengalami pengalaman-pengalaman puncak atau bakat estetis. Selain dari memiliki moral yang tinggi, ia juga mampu memahami nilai-nilai kasih sayang, cinta dan penghargaan. d. Memiliki pemahaman tentang tujuan hidupnya. e. Kelaparan yang terpuaskan terhadap hal-hal yang diminati. f. Pandangan pragmatis dan efesien tentang realitas. Anak dapat melihat situasi sekitar, mau peduli dengan orang disekitar dan peduli dengan kesulitan orang.

\section{Faktor-Faktor yang Mempengaruhi Kecerdasan Spiritual}

Kecerdasan spiritual merupakan kecerdasan tertinggi yang membuat seseorang dapat merasakan bagaimana melangsungkan kehidupannya serta dimana dia berpijak. Danah Zohar mengungkapkan bahwa ada beberapa faktor yang mempengaruhi kecerdasan spiritual yaitu : a. Sel Saraf Otak. Otak menjadi jembatan kehidupan batin dan lahiriah manusia. b. Titik Tuhan (God Spot) Titik Tuhan memainkan peran yang menentukan dalam pengalaman spiritual. Ditambahkan oleh Syamsu bahwa ada beberapa faktor yang mempengaruhi perkembangan spiritual anak, yaitu : faktor internal berupa bawaan manusia yang juga disebut dengan fitrah. Faktor eksternal meliputi lingkungan keluarga, sekolah dan masyarakat.

\section{Aspek-Aspek Kecerdasan Spritual}

Menurut Jalaluddin Rahmat ada beberapa aspek kecerdasan spiritual antara lain : a. Mengenali motif yang paling dalam, di dalam Islam dikenal dengan sebutan fitrah. b. Memiliki tingkat kesadaran yang tinggi, seseorang yang memiliki tingkat kesadaran yang tinggi bearti ia mengenal siapa dirinya dan selalu berupaya untuk mengenali dirinya lebih baik. c. Bersikap respontif pada diri. d. Dapat memanfaatkan kesulitan dan penderitaan, orang yang cerdas secara spiritual ketika mengalami keesulitan, ia tidak akan mencari kambing hitam, akan tetapi akan mengambil hikmah dari penderitaan yang dialaminya. e. Sanggup menentang dan berbeda dari banyak orang, manusia cenderung suka mengikuti masa dan model yang sedang diminati, akan tetapi orang yang cerdas secara spiritual akan menentang hal ini dan 
tidak akan mudah terikut oleh massa dan berani berbeda dari orang lain. f. Tidak Suka mengganggu dan menyakiti orang lain. g.Memberlakukan agama dengan cerdas. h. Memperlakukan kematian dengan cerdas. ${ }^{17}$

Ditambahkan lagi oleh Marsha Sinetar bahwa aspek kecerdasan spiritual sebagai berikut : a) Kemampuan anak untuk dapat memilih. b) Kemampuan anak untuk dapat melindungi. c) Kedewasaan yang diperlihatkan. d) Kemampuan mengikuti cinta. e) Pengorbanan diri, dalam artian anak memiliki sifat pemaaf, mau berkorban untuk orang lain, tidak berburuk sangka, mudah memberi kepada orang lain dan juga selalu ingin membuat orang bahagia. ${ }^{18}$

Dari beberapa point diatas dapat disimpulkan bahwa aspek-aspek dari kecerdasan spiritual ini sangat membantu dalam melakukan sesuatu, jika seseorang memenuhi segala aspek kecerdasan spiritual ini, maka ia akan memiliki kedekatan yang baik dengan Tuhannya dan sesama manusia.

\section{Indikator Kecerdasan Spiritual}

Menurut pendapat Khavari, ada tiga indikator yang dapat dilihat untuk menguji tingkat kecerdasan spiritual seseorang, diantaranya adalah : a. Sudut pandang spiritual dan keagamaan (relasi vertikal, hubungan dengan yang maha kuasa), Sudut pandang ini akan dapat melihat langsung sejauh mana tingkat relasi spiritual kita dengan sang pencipta, hal ini dapat diukur dari "segi komunikasi dan intensitas spiritual individu dengan Tuhannya”. Menifestasinya dapat dilihat dari frekuensi doa. Khavari lebih menekankan segi ini untuk melakukan pengukuran tingkat kecerdasan spiritual, karena "apabila keharmonisan hubungan dan juga relasi spiritual keagamaan seseorang semakin tinggi maka semakin tinggi pulalah tingkat kualitas kecerdasan spiritualnya." b. Sudut pandang relasi sosial-keagamaan, Sudut pandang ini melihat konsekuensi psikologi spiritual keagamaan terhadap sikap sosial yang menekankan segi kebersamaan serta kesejahteraan sosial, kecerdasan spiritual akan tercermin pada ikatan kekeluargaan antar sesama, peka terhadap kesejahteraan orang lain dan juga makhluk hidup lain, bersikap dermawan. Perilaku merupakan menifestasi dari

${ }_{17}$ Tebba, Tasawuf Positif, ( Jakarta: Prenada Media, 2003), h. 56

18 Marsha Sinetar, Kecerdasan Spiritual: Belajar dari Anak yang Mempunyai Kecerdasan Diri,( Jakarta: Elex Media Komputindo, 2001), h. 34 
keadaan jiwa, maka kecerdasan spiritual yang ada dalam diri individu akan termenifestasikan dalam dunia sosial. Jadi dari uaraian ini jelas bahwa kecerdasan ini tidak hanya berurusan dengan Tuhan atau sekedar masalah spiritual, namun akan mempengaruhi pada aspek yang lebih luas terutama hubungan antar manusia. c. Sudut pandang etika keagaamaan, Sudut pandang ini dapat menggambarkan tingkat etika keagaaman sebagai menifestasi dari kualitas kecerdasan spiritual. Semakin tinggi kecerdasan spiritualnya semakin tinggi pula etika keagamaanya. Hal ini dapat terlihat dari ketaatan seseorang pada etika dan moral, jujur, dapat dipercaya, sopan, toleransi dan juga anti dalam kekerasan.

\section{Akhlak}

Akhlak diambil dari bahasa Arab, bentuk jamak dari kata حلق (Khuluqun) yang berarti budi pekerti, perangai, tingkah laku atau tabiat. Kata Khuluqun, merupakan isim jamid lawan dari isim musttaq. Secara terminologi, akhlak adalah sebuah sistem yang lengkap terdiri dari karakteristik akal atau tingkah laku yang membuat seseorang menjadi istimewa. Singkatnya tentang akhlak yang digagas oleh Hanif Yunus, akhlak ialah sifat manusia yang terdidik. ${ }^{19}$ Akhlak merupakan kemampuan jiwa untuk melahirkan suatu perbuatan secara spontan tanpa pemikiran dan paksaan, atau perbuatan yang lahir atas dorongan jiwa berupa perbuatan baik dan buruk. Disinilah peranan falsafah pendidikan Islam untuk merumuskan suatu prinsip, landasan atau tuntunan akhlak al- karimah sejak dini. Sehingga perbuatan-perbuatan yang baik itu timbul secara spontan. Untuk memahami agama secara tepat dan baik, maka diperlukan pendidikan khususnya agama yang mencakup segala aspek hubungan manusia dengan manusia, manusia dengan masyarakat, bahkan manusia dengan lingkungan. Dengan demikian, antara pendidikan dan akhlak tidak bisa dipisahkan. Pendidikan akhlakul karimah adalah jiwa dari pendidikan Islam. Mencapai suatu akhlak yang sempurna adalah tujuan utama pendidikan. ${ }^{20}$. Akhlak juga merupakan

${ }^{19} \mathrm{Abdu}$ al-Hamid Yunus dikutip olehNasharuddin, Akblak Ciri Manusia Paripurna, Jakarta: Rajawali Pers, 2015), h. 207

20 Munirah, Ablak Dalam Persektif Pendidikan Islam Morals In Perspective Islam Education, Auladuna: Jurnal Pendidikan Dasar Islam, Vol. 4 No. 2, December 2017, pp. 39-47, Samata Gowa: Fakultas Tarbiyah dan Keguruan UIN Alauddin Makassar. 
sebuah wujud dari apa yang kita fikirkan, yang kita rasakan, dan diwujudkan dalam bentuk perbuatan ataupun prilaku.

Al-Ghazali mengatakan norma-norma kebaikan dan keburukan akhlak ditinjau dari pandangan akal dan syariat agama Islam. Jika Akhlak itu sesuai dengan akal pikiran dan syariat agama Islam maka dinamakan akhlak mulia, begitupun sebaliknya jika akhlak yang tidak sesuai atau bertentangan dengan akal dan syariat Agama Islam maka dinamakan akhlak sesat dan buruk, karena hanya menyesatkan manusia belaka. ${ }^{21}$ Dari segi sifatnya akhlak dibagi kepada dua bagian yaitu akhlak yang terpuji dan (alAkblaq al-Mabmudah) dan akhlak yang tercela (al-Akblaq alMadzmumah). Akhlak al-Mahmudah adalah tingkah laku terpuji yang merupakan tanda keimanan seseorang. Akhlak mahmudah atau akhlak terpuji ini dilahirkan dari sifatsifat yang terpuji pula". 22

\section{Ruang Lingkup Akhlak}

Kahar Mahsyur mengatakan bahwa ruang lingkup akhlak meliputi bagaimana seharusnya sikap seseorang terhadap penciptanya, sesama manusia, serta masyarakat. Disamping itu juga meliputi bagaimana seharusnya bersikap terhadap makhluk lain seperti malaikat, jin, iblis, hewan, dan tumbuh- tumbuhan. Menurut Muhammad Daud Ali Akhlak secara garis besar dibagi menjadi dua, yaitu: Pertama, akhlak kepada Allah dan Kedua, adalah akhlak kepada semuamakhluk ciptaan Allah. ${ }^{23}$ Lebih rinci, Departemen Agama RI membagi ruang lingkup akhlak menjadi tiga bagian berdasarkan objek/sasarannya, yaitu akhlak kepada Allah, akhlak kepada manusia, dan akhlak kepada lingkungan. ${ }^{24}$ a. Akhlak kepada Allah Akhlak terhadap Allah SWT diartikan sebagai sikap atau perbuatan yang dilakukan manusia selaku makhluk kepada penciptanya, yaitu Allah SWT. Ada banyak cara serta kegiatan penanaman nilai-nilai akhlak kepada Allah yang sesungguhnya akan membentuk

${ }^{21}$ Zainuddin, Seluk-beluk Pendidikan dari Al-Ghazali, (Jakarta: Bumi Aksara, 1991),h. 103.

22 MA Djazimi, Pengaruh Kecerdasan Emosional Terbadap Akblak Siswa Maderasah Al-khairiyah Provinsi Banten, Studia Didkatika, Jurnal Ilmiah Pendidikan, Vol. 10, No. 2, 2016, h. 49 352

${ }^{23}$ Mohammad Daud Ali, Pendidikan Agama Islam, (Jakarta: Raja Grafindo Persada, 2008), h.

24 Departemen Agama RI, Buku Teks Pendidikan Agama Islam Pada Perguruan Tinggi Umum, (Jakarta: Direktorat Jenderal Pembinaan Kelembagaan Agama Islam,1999), h. 148- 155. 
pendidikan keagamaan. Nilai-nilai ketuhanan yang sangat mendasar adalah: ${ }^{25}$ a) Iman, b) Ihsan, c) Takwa, d) Tawakkal,e) Syukur,f) Ikhlas, g) Sabar. b. Akhlak terhadap Rasulullah meliputi : a) Mencintai Rasulullah dengan tulus yaitu dengan cara mengikuti sunnahnya. b) Menjadikan Rasulullah sebagai idola serta suri tauladan dalam kehidupan sehari-hari. c) Menjalankan apa yang diperintahkan dan menjauhi semua larangannya. c. Akhlak terhadap sesama manusia, Akhlak terhadap sesama manusia ini meliputi akhlak terhadap orang tua, akhlak terhadap keluarga, akhlak terhadap karib kerabat, tetangga dan masyarakat. Jika kita runut dari awal, adapun akhlak terhadap orang tua meliputi : a) Mencintai orang tua melebihi cinta kepada kerabat lainnya. b) Merendahkan diri kepada kedua orang tua yang diiringi perasaan berkasih sayang. c) Berkomunikasi kepada kedua orang tua dengan baik, menggunakan bahasa yang lemah lembut dan juga sopan. d) Berbuat baik terhadap kedua orang tua. e) Mendoakan kedua orang tua. Kemudian akhlak kepada diri sendiri, bisa dilakukan dengan cara sebagai berikut: ${ }^{26}$ a) Memelihara kebeningan hati nurani mengisinya dengan ilmu agama islam, kemudian diikuti serta diamalkan. b) Menghindari penyakit hati seperti iri, dengki, dan riya. c) Malu melakukan perbuatan jahat. d) Memantapkan rasa ingin untuk senantiasa beribadah dengan ikhlas, tawadhu', zuhud dan lain sebagainya. e) Mengendalikan nafsu insaniyah seperti makan, minum, dan istirahat yang berlebihan. f) Menghilangkan nafsu syaithaniyah seperti haus akan pujian, takabbur dan berkhianat. Akhlak terhadap lingkunganyang dimaksud dengan lingkungan disini adalah segala sesuatu yang berada disekitar kita, baik itu hewan, tumbuhan, maupun benda-benda yang tidak bernyawa lainnya. Hal ini berdasarkan Al-Qur'an yang mengatakan bahwa fungsi manusia adalah sebagai khilafah dimuka bumi ini. Untuk akhlak terhadap lingkungan ialah: a) Memelihara serta sadar akan kelestarian lingkungan hidup. b) Memanfaatkan dan menjaga alam terutama flora dan fauna, hewan yang Allah ciptakan untuk kebutuhan mmanusia dan makhluknya. c) Sayang kepada sesama makhluk ciptaan Allah. Ini selaras dengan yang dikatakan oleh Muhammad Alim bahwa ruang lingkup ajaran akhlak sama

25 Muhammad Alim, Pendidikan Agama Islam; Upaya Pembentukan Pemikiran dan Kepribadian Muslim, (Bandung: Remaja Rosdakarya, 2006 ), h. 153-154.

${ }^{26}$ Muhammad Daud Ali, Op.cit., h.357 
dengan ruang lingkup ajaran Islam itu sendiri, khususnya yang berkaitan dengan pola hubungan. $^{27}$

\section{Faktor-Faktor yang Mempengaruhi Akhlak}

Adapun faktor-faktor yang mempengaruhi terbentuknya akhlak pada prinsipnya dipengaruhi oleh dua faktor utama yaitu faktor internal dan eksternal. ${ }^{28}$ a. Faktor internal, Setiap anak ketika lahir kedunia memiliki naluri keagamaan yang nantinya akan mempengaruhi dirinya, seperti unsur-unsur yang ada dalam dirinya yang turut membentuk akhlak, diantaranya adalah : a) Insting merupakan kesanggupan untuk melakukan hal-hal kompleks tanpa latihan sebelumnya, mengarah pada tujuan yang bearti bagi si anak, dan berlangsung secara spontan. Menurut para ahli psikologi insting berfungsi sebagai motivator penggerak yang mendorong lahirnya tingkah laku. ${ }^{29}$. b) Kebiasaan. c) Keturunan. d) Kehendak atau kemauan keras. Salah satu kekuatan yang berlindung dibalik tingkah laku adalah kemauan keras atau kehendak. Kemauan atau Kehendak adalah suatu fungsi jiwa untuk dapat mencapai sesuatu. e) Hati Nurani, Pada diri manusia terdapat sebuah kekuatan yang sewaktu-waktu memberikan peringatan(isyarat) apabila tingkah laku manusia berada diambang bahaya dan juga keburukan. Kekuatan tersebut adalah suara hati ataupun suara bathin yang didalam bahasa arab disebut dengan dhamir ${ }^{30}$. Adapun fungsi dari hati nurani ini adalah menjadi alarm bagi kita ketika melakukan perbuatan-perbuatan buruk dan hati ini akan berusaha mencegahnya. Untuk menjadikan hati nurani ini lebih peka, harus disertakan dengan Kecerdasan Spiritual. Karena dengan begitu ketika kita melakukan larangan Allah maka batin merasa tidak senang. Akan tetapi ketika kita melakukan hal-hal yang diperintahkan syariat, maka hati kita akan tentram dan merasa lebih dekat dengan Allah. b. Faktor eksternal meliputi : a) Adat Kebiasaan. b) Pendidikan. c) Lingkungan. Kemudian ada tiga aliran yang sudah populer menjelaskan faktor-faktor yang mepengaruhi pembentukan akhlak

${ }^{27}$ Muhammad Alim, Op.cit., h. 156

28 Hasan Bin Ali Hasan Al-Hijazy, Alfikrut Tarbawy Inda Ibnu Qayyim, ter. Muzidi Hasbullah, Manbaj Tarbiyah Ibnu Qayyim, ( Jakarta: Pustaka Al-Kautsar, 2001), h. 203

${ }^{29}$ Zahruddin dan Hasanuddin, Pengantar Studi Akblak,( Jakarta : Grafindo Persada, 2004), h. 314

\footnotetext{
${ }^{30}$ Basumi Imamuddin, Kamus Kontekstual Arab-IndonesiaI, (Depok : Ulinuha Press, 2001), h.
} 
khususnya dan pendidikan pada umumnya yaitu : 1) Aliran Nativisme, Menurut aliran ini bahwa faktor yang paling berpengaruh dalam diri seseorang adalah faktor pembawaan. Jika seseorang sudah memiliki pembawaan ataupun kecendrungan yang baik, maka dengan sendirinya orang tersebutpun akan menjadi baik. 2) Aliran Empirisme, menurut aliran ini faktor yang paling berpengaruh pada pembentukan diri seseorang adalah faktor dari luar, seperti lingkungan sosial, termasuk didalamnya pembinaan dan juga pendidikan yang diberikan. Jadi apabila pembinaan ataupun pendidikan yang diberikan kepada anak itu baik, maka baik pulalah akhlak anak, akan tetapi sebaliknya, apabila pembinaan ataupun pendidikan anak itu buruk, maka akan buruk pulalah akhlak anak tersebut.aliran ini sangat mempercayai akan peranan yang dilakukan oleh dunia pendidika. 3) Aliran Konvergensi, aliran ini berpendapat bahwa pembentukan akhlak anak dipengaruhi oleh faktor internal dan juga faktor eksternal anak. Faktor eksternal anak ini berupa pendidikan dan pembinaan atau melalui interaksi dalam lingkungan sosial ${ }^{31}$

Ditambahkan lagi oleh Nasirudin, ada tiga proses untuk membentuk akhlak yang baik yaitu : 1) Melalui proses pemahaman, pemahaman ini dapat dilakukan oleh diri sendiri maupun orang lain. Proses pemahaman ini berupa pengetahuan dan informasi mengenai betapa pentingnya akhlak mulia dan besarnya kerusakan yang akan ditimbulkan akibat akhlak yang buruk. 2) Melalui proses pembiasaan dan pengalaman langsung. Dengan pembiasan anak dipaksa dan dilatih untuk megendalikan amarah dan syahwatnya dengan melakukan akhlak yang terpuji. Pada awalnya manusia membentuk kebiasaan akan tetapi pada akhirnya kebiasaan itu pulalah yang akan membentuk manusia. 3) Melalui suri tauladan atau contoh yang baik dari orang-orang terdekatnya. Guru bisa contoh yang baik bagi muridnya, orang tua menjadi contoh yang baik pula bagi anak-anaknya, dan kyai menjadi contoh yang baik bagi santri dan umatnya, serta lain sebagainya. ${ }^{32}$ Dengan demikian faktor yang mempengaruhi pembinaan akhlak pada anak ada dua, yaitu dari dalam merupakan potensi fisik, kemauan, kebiasaan, intelektual dan hati (rohaniah) yang dibawa anak sejak lahir, dan faktor dari luar yang dalam hal ini adalah kedua orang tua dirumah, guru disekolah, dan tokoh-tokoh serta pemimpin dimasyarakat. Melalui kerja sama

31 Abudinata, Akblak Tasawnf, (Jakarta : PT. Remaja Rosdakarya Persada, 2000), h.166-167

${ }^{32}$ Nasirudin, Historisitas dan Normativitas Tasawnf, h. 33-34 
yang baik antara tiga lembaga pendidikan tersebut, maka aspek kognitif (pengetahuan), afektif (penghayatan), dan psikomotorik (pengalaman) ajaran yang diajarkan akan terbentuk pada diri anak.

\section{METODE PENELITIAN}

Penelitian ini merupakan penelitian kuantitatif dengan metode deskriptif kuantitatif yang bertujuan untuk mengetahui apakah ada pengaruh dari kecerdasan emosional dan spiritual terhadap akhlak siswa di Sekolah Menengah Pertama SeKecamatan Bangkinang Kota. Adapun populasi dalam penelitian ini berjumlah 2250. pengambilan sampel menggunakan rumus Slovin dengan tingkat error 5\% dengan menggunakan teknik Stratified Random Sampling, maka didapati sampel sebanyak 339 orang siswa di seluruh Sekolah Menengah Pertama Se-Kecamatan Bangkinang Kota. Teknik pengumpulan data ini menggunakan angket dan dokumentasi. Analisis data melalui: 1. uji prasayarat yaitu : a. Uji normalitas, Uji Linearitas, uji Multikolinearitas. 2. Uji Hipotesis. 3. Analisis Regresi berganda.

\section{HASIL PENELITIAN}

\section{Uji Prasyarat}

\section{Uji Normalitas}

Uji normalitas data ini untuk mengetahui apakah distribusi data dari tiap-tiap variabel normal ataupun tidak. Rumusan yang digunakan adalah uji One-Sample Kolmogrov-Smirnov Test. Adapun hipotesis statistik uji normalitas ini berdasarkan probabilitas sebagai berikut : ${ }^{33}$

a. Jika nilai signifikansi (A.Sign) $<0.05$ bearti data yang akan diuji mempunyai perbedaan yang signifikan dengan data normal baku, dengan kata lain data tersebut tidak normal.

b. Jika nilai signifikansi (A.Sign) $>0.05$ bearti data yang akan diuji tidak mempunyai perbedaan yang signifikan dengan data normal baku, dengan kata lain data tersebut normal.

${ }^{33}$ Hartono, Analisis Item Instrumen, (Pekanbaru: Zanafah Fublishing, 2015),h. 166 
Hasil dari uji normalitas ini ditunjukkan oleh tabel dibawah ini :

Tabel I

Hasil Uji Normalitas

One-Sample Kolmogorov-Smirnov Test

\begin{tabular}{|ll|l|}
\hline & & $\begin{array}{l}\text { Unstandardized } \\
\text { Residual }\end{array}$ \\
\hline N & & 339 \\
Normal Parameters & Mean &, 0000000 \\
Most Extreme Differences & Std. Deviation & 12,92274857 \\
\cline { 2 - 3 } & Absolute & 051 \\
\cline { 2 - 3 } & Positive &, 034 \\
& Negative &,- 051 \\
\hline Test Statistic & &, 051 \\
Asymp. Sig. (2-tailed) & &, $035^{c}$ \\
\hline
\end{tabular}

a. Test distribution is Normal.

b. Calculated from data.

c. Lilliefors Significance Correction.

Sumber Data: IBM Statistic Ver.22

Berdasarkan tabel output SPSS tersebut, diketahui bahwa Asiymp. Sign (2-tailed) sebesar $0.035>0.05$. Maka sesuai dengan dasar pengambilan keputusan dalam uji normalitas Kolmogrov-smirnov diatas, dapat disimpulkan bahwa data tersebut berdistribusi normal. Dengan demikian, persyaratan normalitas sudah terpenuhi.

\section{Uji Linearitas}

Uji linearitas dimaksudkan untuk mengetahui ada atau tidaknya linearitas antara masing-masing variabel. Linearitas variabel ini dapat dilihat dari Anova Table pada kolom F ataupun Sign. Dasar pengambilan keputusan dalam uji linearitas ini yaitu :

a. Jika nilai Sign. $>0.05$, maka tidak ada hubungan yang linear antara variabel independent dan veriabel dependent

b. Jika nilai Sign. $<0.05$, maka ada hubungan yang linear secara signifikan antara variabel independent dan juga variabel dependent.

Berikut ini adalah tabel uji linearitas :

\section{Tabel II}

\section{ANOVA Table}

\section{Hasil Uji Linearitas}




\begin{tabular}{|ll|l|l|l|l|l|}
\hline & & $\begin{array}{l}\text { Sum of } \\
\text { Squares }\end{array}$ & Df & $\begin{array}{l}\text { Mean } \\
\text { Square }\end{array}$ & F & Sig. \\
\hline akhlak * Between & $\begin{array}{l}\text { Combine } \\
\text { K.EmosiGroups }\end{array}$ & 15726,113 & 44 & 357,412 & 2,177 &, 000 \\
& $\begin{array}{l}\text { Linearity } \\
\text { Deviation } \\
\text { from } \\
\text { Linearity }\end{array}$ & 6024,995 & 1 & 6024,995 & 36,690 &, 000 \\
& 9701,119 & 43 & 225,607 & 1,374 &, 069 \\
\hline & 48278,506 & 294 & 164,213 & & \\
\hline Within Groups & 64004,619 & 338 & & & \\
\hline
\end{tabular}

Sumber Data: IBM Statistic Ver.22

Berdasarkan tabel output SPSS tersebut, diketahui bahwa Asiymp. Sign (2-tailed) sebesar $0.000<0.05$ Maka sesuai dengan dasar pengambilan keputusan dalam uji linearitas diatas, dapat disimpulkan bahwa ada hubungan yang linear secara signifikan antara variabel kecerdasan emosional dan spiritual terhadap akhlak siswa. Dengan demikian, persyaratan normalitas sudah terpenuhi.

\section{Uji Multikolinearitas}

Uji multikolinearitas ini digunakan untuk mengetahui ada atau tidaknya hubungan yang linear antar variabel independen dalam model regresi. Dalam regresi prasayarat yang harus terpenuhi adalah tidak adanya multikolinearitas. Dalam pengujian ini ada beberapa cara pengambilan keputusan diantaranya adalah :

Pedoman keputusan berdasarkan nilai tolerance :

a. Jika nilai Tolerance $>$ dari 0.10 maka artinya tidak ada terjadi multikolinearitas dalam model regresi

b. Jika nilai Tolerance $<$ dari 0.10 maka artinya terjadi multikolinearitas dalam model regresi

Pedoman keputusan berdasarkan nilai VIF (Variance Inflation Factor)

a) Jika nilai VIF $<10.00$ maka artinya tidak terjadi multikolinearitas dalam model regresi

b) Jika nilai VIF > 10.00 maka artinya terjadi multikolinearitas dalam model regresi 
Untuk melihat hasil dari tabel SPSS, lihat tabel dibawah ini :

Tabel III

Hasil Uji Multikolinearitas

\section{Coefficients $^{\mathrm{a}}$}

\begin{tabular}{|c|c|c|c|c|c|c|c|}
\hline \multirow[b]{2}{*}{ Model } & \multicolumn{2}{|c|}{$\begin{array}{l}\text { Unstandardized } \\
\text { Coefficients }\end{array}$} & \multirow[t]{2}{*}{\begin{tabular}{|l|} 
Standard \\
ized \\
Coeffici \\
ents \\
Beta \\
\end{tabular}} & \multirow[b]{2}{*}{$\mathrm{T}$} & \multirow[b]{2}{*}{ Sig. } & \multirow{2}{*}{\multicolumn{2}{|c|}{$\begin{array}{l}\text { Collinearity Statistics } \\
\text { Tolerance VIF }\end{array}$}} \\
\hline & $B$ & Std. Error & & & & & \\
\hline $\begin{array}{ll}1 & \text { (Constant) } \\
& \text { K.Emosi }\end{array}$ & $\begin{array}{l}50,053 \\
208\end{array}$ & $\begin{array}{l}8,339 \\
, 101\end{array}$ &, 151 & $\begin{array}{l}6,002 \\
2,070\end{array}$ &, 000 &, 496 & 2,018 \\
\hline K.spiritual & 282 &, 093 & 220 & 3,022 &, 003 &, 496 & 2,018 \\
\hline
\end{tabular}

Dependent Variable: akhlak

Sumber Data: IBM Statistic Ver.22

Berdasarkan dari tabel output "Coefficients" dari SPSS pada bagian " Collinearity Statistics" diketahui nilai tolerance untuk variabel Kecerdasan Emosi $\left(\mathrm{X}_{1}\right)$ dan Kecerdasan Spiritual $\left(\mathrm{X}_{2}\right)$ adalah $0.496>0.10$. Sementara, nilai VIF untuk kedau variabel tersebut adalah $2.018<10.00$. Maka mengacu pada pengambilan keputusan dalam uji multikolinearitas dapat disimpulkan bahwa tidak terjadi gejalamultikolinearitas dalam model regresi.

\section{Uji Hipotesis}

Untuk pengujian hipotesis pertama dan kedua yaitu pengaruh Kecerdasan Emosional $\left(\mathrm{X}_{1}\right)$ terhadap Akhlak Siswa $(\mathrm{Y})$ dan pengaruh Kecerdasan Spiritual $\left(\mathrm{X}_{2}\right)$ terhadap Akhlak Siswa $(\mathrm{Y})$ maka dilakukan uji hipotesis dengan ketentuan diterima dan ditolak sebagai berikut :

1. Jika nilai probabilitas $>0.05 \mathrm{maka}_{0}$ diterima

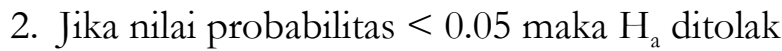

\section{Tabel IV}

\section{Rangkuman Hasil Uji Hipotesis}

Correlations

\begin{tabular}{|cc|c|c|c|}
\hline & & K.Emosi & K.spiritual & Akhlak \\
\hline K.Emosi & Pearson Correlation & 1 &, $710^{* *}$ &, $307^{* *}$ \\
& Sig. (2-tailed) & &, 000 &, 000 \\
& $\mathrm{~N}$ & 339 & 339 & 339 \\
\hline \multirow{2}{*}{ K.spiritual } & Pearson Correlation &, $710^{* *}$ & 1 &, $327^{* *}$ \\
& Sig. (2-tailed) &, 000 & &, 000
\end{tabular}




\begin{tabular}{|c|c|c|c|c|}
\hline & $\mathrm{N}$ & 339 & 339 & 339 \\
\hline Akhlak & Pearson Correlation & $307^{* *}$ & $327^{* *}$ & 1 \\
\hline & $\begin{array}{l}\text { Sig. (Z-talled) } \\
\mathrm{N}\end{array}$ & $\begin{array}{l}, 000 \\
339\end{array}$ & 339 & 339 \\
\hline
\end{tabular}

**. Correlation is significant at the 0.01 level (2-tailed). Sumber Data: IBM Statistic Ver.22

Dari tabel diatas diketahui bahwa pada kolom Kecerdasan Emosional nilai probabilitas atau Sign. (2-tailed) adalah 0.000, maka lebih kecil dari 0.05 (0.000 < 0.05), maka dapat disimpulkan bahwa $\mathrm{H}_{\mathrm{a}}$ diterima dan $\mathrm{H}_{0}$ ditolak yaitu terdapat pengaruh yang signifikan antara Kecerdasan Emosional $\left(\mathrm{X}_{1}\right)$ terhadap Akhlak Siswa (Y) di SMP Se-Kecamatan Bangkinang Kota. Begitu juga dengan tabel Kecerdasan Spiritual nilai probabilitas atau Sign. (2-tailed) adalah 0.000, maka lebih kecil dari $0.05(0.000<0.05)$, maka dapat disimpulkan bahwa $\mathrm{H}_{\mathrm{a}}$ diterima dan $\mathrm{H}_{0}$ ditolak yaitu terdapat pengaruh yang signifikan Kecerdasan Spiritual $\left(\mathrm{X}_{2}\right)$ terhadap akhlak Siswa (Y) di SMP Se-Kecamatan Bangkinang Kota.

Berikutnya untuk menjawab hipotesis ke tiga yaitu apakah ada pengaruh yang signifikan antara Kecerdasan Emosional $\left(\mathrm{X}_{1}\right)$ Kecerdasan Spiritual $\left(\mathrm{X}_{2}\right)$ terhadap Akhlak Siswa (Y)dapat dilihat dari tabel Anova pada uji F. Ada dua cara untuk pengambilan keputusan uji hipotesis ini yaitu :

1. Berdasarkan nilai signifikansi (sig.) dari output Anova

a. Jila nilai sig. $<0.05$, maka hipotesis diterima yaitu Kecerdasan Emosional $\left(\mathrm{X}_{1}\right)$ dan Kecerdasan Spiritual $\left(\mathrm{X}_{2}\right)$ secara simultan mempunyai Korelasi terhadap Akhlak Siswa (Y)

b. Jika nilai sig. $>0.05$, maka hipotesis ditolak, yaitu Kecerdasan Kecerdasan Emosional $\left(\mathrm{X}_{1}\right)$ dan Kecerdasan Spiritual $\left(\mathrm{X}_{2}\right)$ secara simultan tidak mempunyai Korelasi terhadap Akhlak Siswa (Y)

2. Berdasarkan perbandingan nilai $\mathrm{F}$ hitung dengan $\mathrm{F}$ tabel

a. Jika nilai $F$ hitung $>F$ tabel, maka hipotesis ditolak, yaitu Kecerdasan Emosional $\left(\mathrm{X}_{1}\right)$ dan Kecerdasan Spiritual $\left(\mathrm{X}_{2}\right)$ secara simultan mempunyai tidak Korelasi terhadap Akhlak Siswa (Y)

b. Jika nilai $\mathrm{F}_{\text {hitung }}<\mathrm{F}$ tabel, maka hipotesis diterima, yaitu Kecerdasan Emosional $\left(\mathrm{X}_{1}\right)$ dan Kecerdasan Spiritual $\left(\mathrm{X}_{2}\right)$ secara simultan tidak mempunyai korelasi terhadap Akhlak Siswa (Y) 


\section{Tabel V}

Hasil Uji F

ANOVA $^{\mathrm{a}}$

\begin{tabular}{|c|c|c|c|c|c|c|}
\hline \multicolumn{2}{|r|}{ Model } & $\begin{array}{l}\text { Sum of } \\
\text { Squares }\end{array}$ & Df & Mean Square & $\mathrm{F}$ & Sig. \\
\hline 1 & Regression & 7559,488 & 2 & 3779,744 & 22,500 &, $000^{\mathrm{b}}$ \\
\hline & Residual & 56445,132 & 336 & 167,991 & & \\
\hline & Total & 64004,619 & 338 & & & \\
\hline
\end{tabular}

a. Dependent Variable: akhlak

b. Predictors: (Constant), K.Spiritual, K.Emosi

Sumber Data IBM Statistik. Ver. 22

a. Berdasarkan Nilai Signifikan (sig.) dari output Anova

Berdasarkan tabel output diatas diketahui bahwa nilai sig. Pada uji F adalah sebesar $0.000<0.05$, maka sebagaimana dasar pengambilan keputusan dalam uji f disimpulkan bahwa $\mathrm{H}_{\mathrm{a}}$ diterima atau dengan kata lain ada pengaruh antara kecerdasan emosional $\left(\mathrm{X}_{1}\right)$ kecerdasan spiritual $\left(\mathrm{X}_{2}\right)$ secara simultan (bersama-sama) terhadap Akhlak Siswa (Y) atau bearti signifikan.

b. Berdasarkan perbandingan nilai $\mathrm{F}_{\text {hitung }}$ dengan $\mathrm{F}_{\text {tabel }}$

Berdasarkan tabel output diatas, diketahui bahwa tabel F hitung adalah sebesar 22.500, dikarenakan nilai $\mathrm{F}$ hitung $22.500>\mathrm{F}$ tabel 3.022, maka sebagaimana dasar pengambilan keputusan dalam uji $\mathrm{f}$ disimpulkan bahwa $\mathrm{H}_{a}$ diterima atau dengan kata lain ada korelasi antara kecerdasan emosional $\left(\mathrm{X}_{1}\right)$ kecerdasan spiritual $\left(\mathrm{X}_{2}\right)$ secara simultan (bersama-sama) dengan Akhlak Siswa (Y) atau bearti signifikan.

\section{Analisis Regresi Berganda}

Analisa regresi berganda merupakan suatu analisis yang digunakan untuk mengukur sejauh manakah pengaruh satu atau beberapa variabel bebas terhadap variabel terikat, baik itu secara parsial maupun slimultan, kriteria pengujian analisis ini adalah :

1) Jika nilai Sign dari tabel coefficients $<0.05$ maka $H_{a}$ diterima dan $H_{0}$ ditolak, dalam artian ada pengaruh yang signifikan antara variabel bebas terhadap variabel terikat 
2) Jika nilai Sign dari tabel coefficients $>0.05$ maka $H_{0}$ diterima dan $H_{a}$ ditolak, dalam artian tidak ada pengaruh yang signifikan antara variabel bebas terhadap variabel terikat

untuk melihat arah regresi dari ketiga variabel ini dapat dilihat dari tabel berikut:

\section{Tabel VI \\ Koefisien Persamaan Regresi Berganda}

\section{Coefficients $^{\mathrm{a}}$}

\begin{tabular}{|cc|c|c|c|c|c|}
\hline & \multicolumn{2}{|c|}{$\begin{array}{c}\text { Unstandardized } \\
\text { Coefficients }\end{array}$} & $\begin{array}{c}\text { Standardized } \\
\text { Coefficients }\end{array}$ & & \multirow{2}{*}{ Sig. } \\
\cline { 3 - 5 } & \multirow{2}{*}{ Model } & $\mathrm{B}$ & Std. Error & Beta & $\mathrm{T}$ & Sig. \\
\hline \multirow{2}{*}{1 (Constant) } & 50,053 & 8,339 & & 6,002 &, 000 \\
& K.Emosi &, 208 &, 101 &, 151 & 2,070 &, 039 \\
& K.spiritual &, 282 &, 093 &, 220 & 3,022 &, 003 \\
\hline
\end{tabular}

a. Dependent Variable: akhlak

Sumber Data: IBM Statistic Ver.22

Dari tabel VI hasil analisis menunjukkan nilai constanta sebesar 50.053, nilai Kecerdasan Emosional $\left(\mathrm{X}_{1}\right)$ sebesar 0.208 serta nilai Kecerdasan Spiritual sebesar 0.282. Untuk signifikan dari Kecerdasan Emosional adalah $0.039>0.05$ berdasarkan hasil tersebut $\mathrm{H}_{\mathrm{a}}$ ditolak dan $\mathrm{H}_{0}$ diterima. Kemudian untuk signifikan dari Kecerdasan Spiritual adalah $0.003<0.05$ berdasarkan hasil tersebut $\mathrm{H}_{a}$ diterima dan $\mathrm{H}_{0}$ ditolak. Dengan demikian kecerdasan spiritual lebih besar pengaruhnya terhadap akhlak siswa dari pada kecerdasan emosional.

Selanjutnya untuk melihat nilai koefisien determinasi atau kontribusi atau sumbangan pengaruh variabel kecerdasan emosional dan spiritual secara simultan (bersama-sama) dengan akhlak siswa dapat dilihat pada tabel dibawah ini :

Tabel VIII

Koefisien Determinasi

Model Summary

\begin{tabular}{|l|l|l|c|c|}
\hline Model & $\mathrm{R}$ & R Square & $\begin{array}{c}\text { Adjusted R } \\
\text { Square }\end{array}$ & $\begin{array}{c}\text { Std. Error of } \\
\text { the Estimate }\end{array}$ \\
\hline
\end{tabular}




\section{\begin{tabular}{|l|r|r|r|r|}
\hline 1 &, $344^{\mathrm{a}}$ &, 118 &, 113 & 12,961 \\
\hline
\end{tabular}}

a. Predictors: (Constant), K.spiritual, K.Emosi

Sumber Data: IBM Statistic Ver.22

Berdasarkan tabel VIII diatas, diketahui bahwa nilai koefisien determinasi atau $\mathrm{R}$ square adalah sebesar 0.118 , nilai $\mathrm{R}$ square ini berasal dari pengkuadratan nilai koefisien korelasi atau "R" yaitu 0.344 x 0.344. Besarnya angka koefisien determinasi ( $\mathrm{R}$ square) adalah 0.118 atau sama dengan $11.8 \%$. Angka tersebut mengandung arti bahwa pengaruh variabel kecerdasan emosional $\left(\mathrm{X}_{1}\right)$ dan variabel kecerdasan spiritual $\left(\mathrm{X}_{2}\right)$ dengan variabel akhlak siswa (Y) secara simultan sangat rendah. Sedangkan sisanya 88.2\% dipengaruhi oleh variabel lain diluar dari persamaan regresi ini ataupun dari variabel yang tidak diteliti

\section{KESIMPULAN}

Setelah melakukan analisis data pada penelitian ini dengan judul "Pengaruh Kecerdasan Emosional dan Spiritual Terhadap Akhlak Siswa di Sekolah Menengah Pertama Se-Kecamatan Bangkinang Kota" dapat ditarik kesimpulan: 1. Terdapat pengaruh dari Kecerdasan Emosional terhadap Akhlak Siswa di Sekolah Menengah Pertama Se-Kecamatan Bangkinang Kota dengan nilai signifikan 0.000 < 0.05. 2. Terdapat pengaruhdari Kecerdasan Spiritual terhadap Akhlak Siswa di Sekolah Menengah Pertama Se-Kecamatan Bangkinang Kota dengan nilai signifikan $0.000<$ 0.05. 3. Terdapat pengaruh yang signifikan dari Kecerdasan Emosional dan Spiritual terhadap Akhlak Siswa di Sekolah Menengah Pertama Se-Kecamatan Bangkinang Kota dengan nilai Signifikan $0.000<0.05$.

\section{DAFTAR PUSTAKA}

A.A.Anwar Prabu Mangkunegara dan Mela Puspitasari. 2015. Kecerdasan Emosi, Stres Kerja dan Kinerja Guru, Jurnal Pendidikan,Vol. 45. Nomor 2. November

Abdu al-Hamid Yunus dikutip olehNasharuddin. 2015. Akblak Ciri Manusia Paripurna. Jakarta: Rajawali Pers

Abdul Mujib \& Jusuf Mudzakir. 2001. Nuansa-NuansaPsikologi Islam. Jakarta: Rajawali Press

Abudinata. 2000. Akblak Tasawuf. Jakarta : PT. Remaja Rosdakarya Persada 
Ary Ginanjar. 2007. Rahasia Sukses Membangun Kecerdasan Emosi dan Spiritual ESQ Emotional Spiritual Quotion The ESQ Way 1651 Ihsan 6 Rukun Iman dan 5 Rukun Islam. Jakarta: Penerbit Agra

Baharuddin dan Rahmatia Zakaria. 2018. Pengarub Kecerdasan Spiritual Terhadap Peningkatan Kinerja Guru di SMA Negeri 3 Takalar Kabupaten Takalar. Jurnal Idaarah. Vol.2. No.1. Juni. Malang: Fakultas Tarbiyah dan Keguruan UIN Alauddin Makasar.

Basumi Imamuddin. 2001. Kamus Kontekstual Arab-IndonesiaI. Depok : Ulinuha Press

Daniel Goleman. 1996. Emotional Intelligece. Jakarta : Gramedia Pustaka Utama

Departemen Agama RI. 1999. Buku Teks Pendidikan Agama Islam Pada Perguruan

Tinggi Umum. Jakarta: Direktorat Jenderal Pembinaan Kelembagaan Agama Islam

Djazimi. 2016. "Pengaruh Kecerdasan Emosional Terhadap Akblak Siswa Madrasah Aliyah AlKhairiyah Provinsi Banten". Studia Didkatika Jurnal Ilmiah Pendidikan. Vol.10. No.2

Hamzah B. Uno. 2012. Orientasi Barudalam Psikologi Pembelajaran. Jakarta : PT. Bumi Aksara

Hartono. 2015. Analisis Item Instrumen. Pekanbaru: Zanafah Fublishing

Hasan Bin Ali Hasan Al-Hijazy, Alfikrut Tarbawy Inda Ibnu Qayyim, ter. Muzidi Hasbullah. 2001. Manhaj Tarbiyah Ibnu Qayyim. Jakarta: Pustaka Al-Kautsar

Jhon. P.Miller. 2002. Cerdas di Kelas Sekolah Kepribadian, Terjm. Abdul Munir Mulkhan. Yogyakarta : Kreasi Wacana.

MA Djazimi. 2016. Pengarub Kecerdasan Emosional Terhadap Akblak Siswa Maderasah Alkhairiyah Provinsi Banten. Studia Didkatika. Jurnal Ilmiah Pendidikan. Vol. 10. No. 2

Marsha Sinetar. 2001. Kecerdasan Spiritual: Belajar dari Anak yang Mempunyai Kecerdasan Diri.Jakarta: Elex Media Komputindo.

Mohammad Daud Ali. 2008. Pendidikan Agama Islam. Jakarta: Raja Grafindo Persada

Muhammad Alim. 2006. Pendidikan Agama Islam; Upaya Pembentukan Pemikiran dan Kepribadian Muslim. Bandung: Remaja Rosdakarya

Munirah. Ablak Dalam Persektif Pendidikan Islam Morals In Perspective Islam Education, Auladuna: Jurnal Pendidikan Dasar Islam, Vol. 4 No. 2, December 2017, pp. 39-47, Samata Gowa: Fakultas Tarbiyah dan Keguruan UIN Alauddin Makassar.

Ni Luh Putu Ani Cahyani. Pengaruh Kecerdasan Emosonal, Motivasi, dan Pelatihan terhadap Kinerja Aparatur Sipil Negaradi BiroUmum Sekretariat Daerah Provinsi Sulawesi Utara.

Nurul Zuriyah. 2008. Pendidikan Moral dan Budi Pekerti dalamPerspektif Perubahan. Jakarta: Bumi Aksara

Sukidi. 2002. Rahasia Sukeses Hidup Bahagia Kecerdasan Spiritual Mengapa SQ Lebih Penting daripada IQ dan EQ.Jakarta: Gramedia

Tebba. 2003. Tasawuf Positif.Jakarta: Prenada Media

Triantoro Safaria. 2007. Spiritual Intellegence Metode Pengembangan Kecerdasan Spiritual Anak. Yogyakarta : Graha Ilmu

Zahruddin dan Hasanuddin. 2004. Pengantar Studi Akblak. Jakarta : Grafindo Persada Zainuddin. 1991. Seluk-beluk Pendidikan dari Al-Ghazali. Jakarta: Bumi Aksara 